\title{
Surveying of Importance of Green Marketing Compared Purchase Budget and Preferred Brand when Buying by AHP Method
}

\author{
Mahbubeh Esmaili* \\ Seyede Fatemeh Fazeli \\ Department of Business management, Faculty of Economic and Management Sciences, Urmia University, Urmia, Iran \\ *Corresponding Author Email: esmaeli.mahbubeh@hotmail.com
}

\section{Doi:10.5901/mjss.2015.v6n4p388}

\section{Abstract}

Competition among green factories increased due to significant changes in demand for green products. Current project has been done to make a comprehensive comparison between green marketing mix, with common factors influencing purchase decision of consumers, such as purchase budget, and brand preference. The participants of the present study were all citizens of Shiraz city. By using Krejcie and Morgan table and casual method, the researchers selected a population of 384 with respect to the proportional size of eleven municipality region of Shiraz. Decision tree of this project designed based on theoretical studies on green marketing mix, and consumer buy green. Based on this, we designed questioner paired comparison, and then data have been collected. Analytic Hierarchy Process (Super Decision) was used to analyze the data. Therefore, statistical analysis showed that all the elements of marketing mix showed priority to purchase budget, and brand preference. These data also showed a priority of consumer are, green products, green price, the green activities promote, green distribution, purchase budget, and brand preference.

Keywords: Green marketing, brand preference, social marketing, AHP.

\section{Introduction}

Nowadays, environment is a vital and inseparable factor from human activity, ranging from politics, economy, security, culture, etc. Green marketing is trying to create inextricably Connection between environment and marketing to social responsibility of marketing management.

Green marketing is a strategic issue. Integrating environmental issues into strategic marketing process has become essential, instead of voluntary, for firms to achieve institutional legitimacy and competitive advantage (Chan \& Wan, 2012). In recent years, due to environmental pollution of industrial production, the environmental issues are increasingly recognized. There is growing concern about environmental issues at the global level. Consumer awareness increased and they have been found that purchasing can cause serious damage to the ecological balance of the earth (Rahbar, 2008). In the early years, introducing the concept of green marketing with increasing criticism and environmental action groups, people to their environment, ended resources and efficient use of them according to the needs of future generation, found greater awareness and in this regard, approach green consumption was greater popularity among the population. The logic of this approach is preventing harm to the environment and economic activities by reducing the production and consumption (haghighi \& khalili, 2011).

In this regard to the issue of green marketing, pay attention to the importance of the concept of green marketing, the budget and preferred brand than chief elements impact on people's buying decision.

\section{Theoretical Study of Research}

\subsection{Social Responsibility}

Social Responsibility generally refers to business decision making linked to ethical values, compliance with legal requirements, and respect for people, communities and the environment. In fact, Social responsibility going beyond the the legal, technical, and economic requirements of the company, and effort to improve the quality of community life (Karna, \& Hansen, \& Juslin, 2003). Although parts of the concept of social responsibility refereed to environmental issues that encourage the organization especially, scratch marketing and accept the decisions base on green basics, but it 
should be noted expressing that social responsibility simply take environmental issues is simplicity, because this commitment will have a great impact on organizational operations and caused extensive adjustments that result in different parts. In this approach, not only the environment and ecosystem, but also mental and physical health of present and future customer of organization and such other people who consume the products of organization are consider and even problems such as population growth also pay attention ( Kotler \& Armstrong, 2008).

\subsection{Green Marketing:}

Green Marketing is a social process which people and groups compensate their needs by an ethical manner that will minimize negative impacts on the environment (kotler, 2003).

\subsection{Green Marketing Mix:}

Green marketing includes green product, green price, green promotes and green distributions. Green product is the most important elements in marketing. The aim of ecological lead design of products is to reduce pollution. In addition, Green product help to preserve the natural environment and reduce or the removal of pollutants and lesions. Price green is also one of the most important elements in green marketing. Green products are often higher price than traditional products. They often have higher costs of primary output, but their long-term costs are lower. Majority of consumers, are willing to pay a higher price if they receive value added product. Green Promote means transfer of real environmental data to consumers which associated with the company's activities. Green distribution has two aspects: (a) internal aspect, and (b) external aspect. In internal aspect, in addition to environmental compliance issues at company's internal processes, managers and employees should feel safe, whereas in external aspect, places should be selected that lead least damage to the environment (Polonsky \& Rosenberger, 2001).

\subsection{Purchase Budget}

In this study, the means of the purchase budget is the amount of household income that will relate to specific purchase something and the person at the time of purchase willing not to pay more for the product.

\subsection{Brand Preference}

Brand preference is closely associated with brand choice that can facilitate consumer decision making and activate brand purchase. Knowing the pattern of consumer preferences across the population is a critical input for designing and improving innovative marketing strategies. It also reveals the heterogeneity of consumer choices leading to efficient market segmentation strategies. However, predicting consumer's preferences between brands is not an easy task. Most of the early models are a basis on brand attributes in preference construction (Fishbein, 1965).

\section{Statement of the Problem and Significance of the Study}

Increased pollution and environmental damage, the necessity of providing unlimited use of limited resources, the rising cost of energy types and other reasons such as these, people about environmental concerns raised the consequence of such view was a large change in the name of marketing approaches to social responsibility. Based on this approach to marketing, consumer products organization are not only those consumers who buy and use the product directly to the action, but also all human beings are indirect consumer products of the organization and the production and the marketing of products should also consider the needs of the group.

The fundamental opportunity which developed by using green marketing is the new playing field with few competitors. In greening, a company can have several points such as improving resource efficiency, lower cost structure of the company, and improving the competitive position. With regard to the points mentioned and clarify the importance of addressing the issue of social responsibility and addressing green marketing in this article, the researchers want to consider this issue that, when purchasing products, priority of consumers is budget and preferred brand or green marketing's factors?. According to the statistics, the researchers can be found that social responsibility and green marketing topics to what extent is important for the target population? In addition, according to the results, it can be concluded the proposed solutions to further promote green marketing purposes or even known to the public. Because 
wishing push people to buy green products and rising demand for these products companies and suppliers have more effort to improve the social responsibility and coordinate their products with green standards for survival and profitability in a competitive market.

\section{A Review of Conducted Research}

Lee in his research identifies important factors that influence over the behavior of young consumers buy green. The results showed that the most important factors consisted of impact on society, environmental significance, environmental protection, and environmental responsibility (Lee, \& Lawson-Body, 2010). ). Tondkar et al., conducted a research entitled "influence of green marketing and consumer buying behavior low consumption lamps of Rasht which was sampling and through cluster method and data gathering by interviews and questionnaires, They found that there are significant relationships between consumer buying behavior and each of the elements of green marketing mix (Tondkar \& Ramezanian \& Esmaeilpour, 2010). In another research, entitled the effect of green marketing mix on customer loyalty to brand of green marketing company, the aim of study was to investigate the effect of green marketing as one of the important variables for customers of the world's sugar company. The results of research showed that the elements of green marketing affect the customer loyalty and brand of the company and influence patterns of green marketing is a suitable value according to structural parameters (hosseinzadeh \& rashidpoor \& safari, 2014). According to the investigation, and according to studies included in Table 1 below, parameters for each marketing standards were obtained by using previous research, and the operating budget and brand preference are identified the most important influence factors in the statistical population of 384 patients with primary interviews on customers' purchase decisions. Due to the fact that previous studies may have been paid under the budget to buy and user preferences, the two benchmark indices according to individual studies were realized.

Table 1. Criteria and indicators to assess

\begin{tabular}{|c|c|}
\hline Criteria & Indicators \\
\hline Green price & $\begin{array}{l}\text { providing good value for the price paid (Lee, \& Lawson-Body, 2010), (Johri \& Sahasakmontri, 1998), (Xia \& } \\
\text { Herrmann \& Monroe \& Huber 2007) }\end{array}$ \\
\hline Green product & $\begin{array}{l}\text { contain elements that are not harmful to the environment (Mahenc, 2008) \& (Polonsky \& Rosenberger, 2001) } \\
\text { made of materials that can be recycled to provide product (Dangelico \& Pontrandolf, 2009), (Chen \& Chai2010) } \\
\text { Its production process is environmentally friendly (Gurau \& Ranchhod, 2005). }\end{array}$ \\
\hline $\begin{array}{l}\text { Green promotions } \\
\text { activities }\end{array}$ & $\begin{array}{l}\text { promote a green lifestyle (Cox, 2008) } \\
\text { statement of the company's environmental responsibility (Cox, 2008) } \\
\text { Illustrate the environmental characteristics of products (Polonsky \& Rosenberger, 2001) } \\
\text { increase consumers' awareness of the environmental issues (Polonsky \& Rosenberger, 2001) }\end{array}$ \\
\hline $\begin{array}{l}\text { Green distribution } \\
\text { purchase budget }\end{array}$ & $\begin{array}{l}\text { product availability(Tondkar \& Ramezanian \& Esmaeilpour, 2010) } \\
\text { Check the customer's willingness to pay more for a green product with the same functionality than the non- } \\
\text { green products. }\end{array}$ \\
\hline Brand preference & $\begin{array}{l}\text { matching brand with customer requirements ( Malhotra, 1988) } \\
\text { Check the green product rather than known brand and customer favorite }\end{array}$ \\
\hline
\end{tabular}

\section{Research Hypothesis}

Hypothesis 1: Green product is a higher priority than the purchase budget when customers buying decision. Hypothesis 2: Green product is a higher priority than the brand preference when customers buying decision. Hypothesis 3: Green price is a higher priority than the purchase budget when customers buying decision. Hypothesis 4: Green price is a higher priority than the brand preference when customers buying decision. Hypothesis 5: Green promotes activities is a higher priority than the purchase budget when customers buying decision.

Hypothesis 6: Green promotes activities is a higher priority than the brand preference when customers buying decision.

Hypothesis 7: Green distributes is a higher priority than the purchase budget when customers buying decision.

Hypothesis 8: Green distribution is a higher priority than the brand preference when customers buying decision. 


\section{Methodology}

The present research is based on theatrical research and in term of data collection is a descriptive survey. The main objective of this study was to determine the importance of green marketing to customers when they purchase decision is the budget and preference.

In this study, the researchers used the investigative methods such as libraries and filed for data collection like questionnaire.

Questionnaires for prorating of main criteria were used by paired comparison's techniques. The questionnaires determined based on the spectrum $9{ }^{\circ}$ clock. Hierarchical group according to result of paired comparisons' questionnaires were used based on the spectrum $9^{\circ}$ clock that is a scientifically accepted method adopted by many researchers. These questionnaires have a logical and content approach of the variables in determining relative weight of variables. Because in questionnaires all the HBM were considered and compare them together, therefore, all the possibilities related to the neglect of a variable disappears. Since the questionnaire, compare and evaluate all criteria two by two, the most questions asked from audience are favorable structure and because all the criteria considered in this assessment and designer doesn't need to specific design, there is no need to assess reliability and in the other hand because the questionnaires are based on AHP and time scale, the survey questionnaire was used to measure the result of incompatibility. This indicator suggests that if the mismatch of paired comparisons is more than 0.1 , it is better to revise the comparison. For data analysis, AHP technique and super decisions software was used.

In this study, before the questionnaire was completed by respondents, questions in the questionnaire were available in a complete and written form till data become analyzed with greater confidence. Also because the respondent have a clear understanding of green product, the newspaper pencil that is produced from waste paper, mentioned as green products.

Statistical population of the city is the citizens of Shiraz. The research sample specified using elementary sampling proportional according to population size. The study population divided into eleven categories that consist of $11^{\text {th }}$ municipal areas in the city of Shiraz. The mentioned sample was selected by a suitable principle proportional to the size of each class. krejcie and Morgan's table, at 95 percent, sample of 384 members with a membership of 1,000,000 to $5,000,000$ considered enough for societies, with the assumption that the population is in this range.

\section{Decision Tree in Hierarchical Analysis}

The first step in priority of elements which affected green buys decision by using AHP, is establishing decision tree in hierarchical analysis that exist in figure (1).

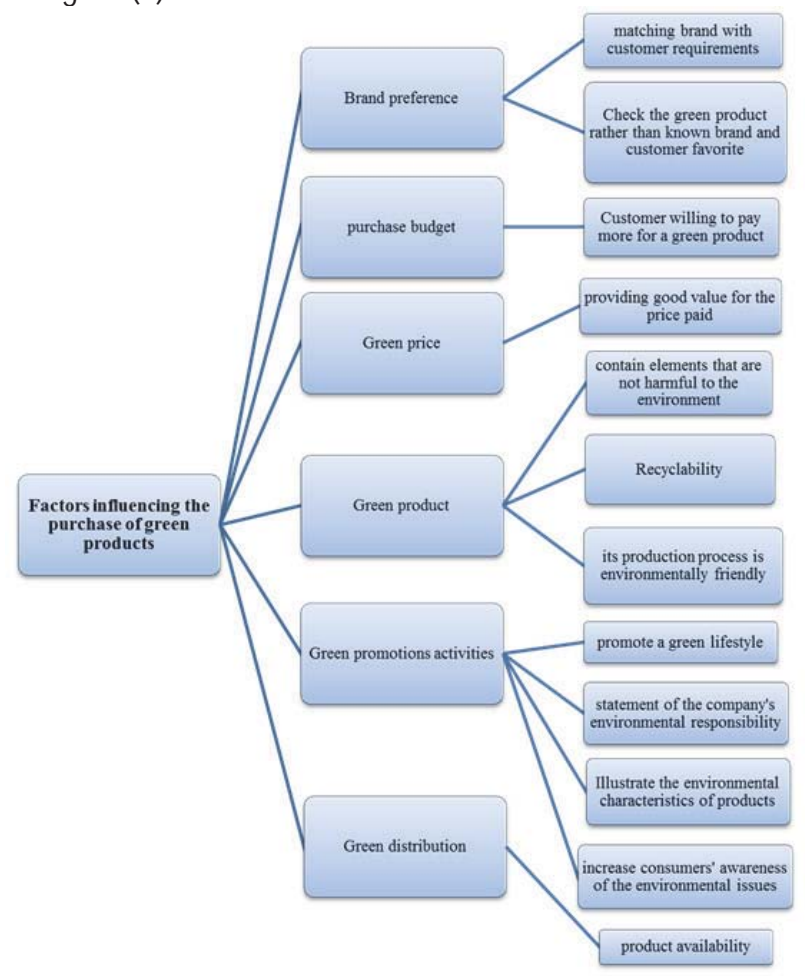

Figure (1). Decision tree in hierarchical analysis 


\section{Results}

By paired comparison of main criteria, coefficient of each of the main criteria are calculated that their result show in table (2).

Table 2. Main criteria for determining the priority

\begin{tabular}{|cccccccc|}
\hline & Price & Product & Promotion & Need & Budget & Brand preference & specific vectors \\
\hline Price & 1 & 1.885 & 1.835 & 1.560 & 1.698 & 1.671 & 0.222 \\
Product & 0.531 & 1 & 3.306 & 2.555 & 2.267 & 3.248 & 0.260 \\
Promotion & 0.545 & 0.302 & 1 & 2.305 & 2.918 & 2.305 & 0.162 \\
Distribution & 0.641 & 0.391 & 1.722 & 1 & 2.405 & 1.337 & 0.150 \\
Budget & 0.589 & 0.308 & 0.343 & 0.416 & 1 & 2.252 & 0.092 \\
Brand preference & 0.599 & 0.441 & 0.434 & 0.748 & 0.444 & 1 & 0.083 \\
\hline
\end{tabular}

Based on the obtained specific vector, the highest priority is the product of normal weight 0.260 . Green prices with normal weight 0.222 is the second priority. The third priority is the promotion of green-weight normalized 0.162 .The fourth priority to green distribution with normal weight $0 / 150$ is assigned to suck and fifth and sixth, respectively, budget and personal preference with normal weight 0.092 and preferred brand with 0.083 normal weight. Adjustment factor of all conducted comparing are equal to 0.075 and smaller than 0.1 , so the results of finished comparing is valid and trustful.

Table (3) shows the priority of indicators of green product. According to specific vector which show in table (3), the product is not harmful to the environment elements with normal weight 0.377 is the first priority, recyclability 0/363 is the second priority, being friendly production process with normal weight 0.266 is the third priority are the main factor of the green products. Also all adjustment factor of conducted comparing are equal to 0150/ and smaller than 0.1 .

Table 3. Determine the priority of the Indicators of Green product

\begin{tabular}{|lcccc|}
\hline & $\begin{array}{c}\text { Contain Elements that are not } \\
\text { Harmful to the Environment }\end{array}$ & Recyclability & $\begin{array}{c}\text { Its Production Process is } \\
\text { Environmentally Friendly }\end{array}$ & $\begin{array}{c}\text { Specific } \\
\text { Vector }\end{array}$ \\
\hline $\begin{array}{l}\text { Contain elements that are not } \\
\text { harmful to the environment }\end{array}$ & 1 & 0.856 & 1.700 & 0.377 \\
$\begin{array}{l}\text { Recyclability } \\
\text { Its production process is }\end{array}$ & 1.168 & 1 & 1.110 & 0.363 \\
environmentally friendly & 0.588 & 0.901 & 1 & 0.266 \\
\hline
\end{tabular}

Base on table (4) and according to specific obtained vector, increased awareness of consumers towards environmental issues with normal weight 0.288 is the first priority, expressing environmental characteristics of products with normal weight 0.244 is the second priority, promoting green lifestyle with normal weight 0.233 is the third priority and expressing environmental responsibility with normal weight 0.299 is the forth priority. Also all adjustment factor of conducted comparing are equal to 0.015 and less than 0.1 .

Table 4. Determine the priority of the Indicators of Green promotions activities

\begin{tabular}{|lccccc|}
\hline & $\begin{array}{c}\text { Promoting } \\
\text { green } \\
\text { lifestyle }\end{array}$ & $\begin{array}{c}\text { Expression of } \\
\text { environmental } \\
\text { responsibility }\end{array}$ & $\begin{array}{c}\text { Expression of } \\
\text { environmental } \\
\text { Product Features }\end{array}$ & $\begin{array}{c}\text { Increase consumers' } \\
\text { awareness of the } \\
\text { environmental issues }\end{array}$ & $\begin{array}{c}\text { Specific } \\
\text { vector }\end{array}$ \\
\hline Promoting green lifestyle & 1 & 0.937 & 0.962 & 0.891 & 0.233 \\
Expression of environmental responsibility & 1.067 & 1 & 1.122 & 0.603 & 0.229 \\
Expression of environmental Product Features & 1.039 & 0.891 & 1 & 1.025 & 0.244 \\
Increase consumers' awareness of the & 1.122 & 1.660 & 0.976 & 1 & 0.288 \\
environmental issues & & & & 1 & \\
\hline
\end{tabular}

\section{Conclusions}

As the results showed, all studies were confirmed and this determined that the elements of green marketing compared to brand preference and budget have high priority in customers buying decision. According to the results observed 
everything that among the factors that significantly influence the purchasing decision, its results in a green product is the most important factor ,therefore, it is clear that notion of suppliers is to green products which include product which is not harmful to the environment component elements, grabber recycling, and oriented environment of the production process, in addition to attract costumer satisfactory and recessive high profit, have a high and suitable effect on conducting of brand's social responsibility and suppliers of goods and is a useful step toward global concern over environmental pollution.

It should be noted the important point that just recycling of a good is not an advantage; the condition of recycling should be provided.

Companies can create a simple demand for environment-friendly products by production new product and strategy of business models and a complete new business (Olsan, 2009).

For having green product should create a green infrastructure. It means that by using clean energy like solar energy production, using green supply chain, using green line in production, using green packaging for products and providing recycling facilities that causes economic benefits for companies, can claim that we deliver green product for green consumer in mall and after these action by applying green marketing activities fulfilled social responsibility.

The price of green products that according to analyzing were given second priority are very important factors that due to its importance at satisfying customer and crating profit for companies, receive specific attention. Although there are customers who are willing to pay more money for real supporting of environment and products which are protects environmental standards and according to result of this research seems that majority of people more than product's price, pay attention to their greenness, because the effeteness of buying budget factor in green buying is in second priority, however, because of income and economical pressure on families, price is a key element on people's green buy decisions, so it is necessary that producers pay attention to all elements by useful strategies and before that create a effective and clear research in pointed society. The results in analyzing promotion of green pointed out that consumers willing to do environmental factors before promoting programs and after that the green features of products become cleared. By paying attention to these factors, people willing effective and useful life toward green living. Although the distribution is in forth priority in this research, it is very important element because other products are useful if the green product became available for consumers and if not other products won't be useful.

Nowadays, internet shopping system palyed an effective role in green distribution, for this reason, the product became available in more easy way for nearest and far people of pointed society and people do not need to commuting with transportation in environment to buy their needs.

The surveys show that greenness of a brand is preferred even if it is unknown or new. In addition, results and priorities which mentioned can be used in strategies in such way that will cause and create challenging.

\section{References}

Bruwer, J. and Buller, C. (2012). Country-of-origine (COO) brand preferences and associated knowledge levels of Japanese wine consumers. Journal of Product \& Brand Management, 21(5): pp. 307-316.

Chan, H.K., He.H., Wang, W.Y.C. (2012). Green marketing and its impact on supply chain management in industrial markets. Industrial Marketing Management, Vol 41, pp. 557-562.

Chen ,T.B and Chai, L.T. (2010). Attitude towards the Environment and Green Products: Consumers' Perspective. Management Science and Engineering, Vol 4, pp. 27-39.

Cox, M. J. (2008). Sustainable Communication: A Study of Green Advertising and Audience Reception.

Dangelico, R. M., and Pontrandolf, P. P. (2009). From green product definitions and classifications to the Green Option Matrix. Journal of Cleaner Production, 1608-1628.

Fishbein, M. (1965). A consideration of beliefs, attitudes, and their relationships. In Seteiner, J. \& Fishbein, M. Current studies in Social Psychology, (pp. 107-117). New York: Holt, Rinehart, and Winston.

Gurau , C.\& Ranchhod, A. (2005). International green marketing a comparative studyof british and Romanian firms. International marketing review, 22(5): pp. 547-561.

Haghighi, M. and KHalili, M. (2011). Investigation of Green Marketing Position of in Consumer's Buying behavior. 24(9): pp 83-102.

Hosseinzadeh, S., Safari, A. and Rashidpoor, A. (2014). Effect of green marketing mix elements on customer's loyalty to brand Naghsh e Jahan Sugar co. New Marketing Research Journal, 4(2): pp. 111-124.

Johri, L. M. and Sahasakmontri, K. (1998). Green marketing of cosmetics and toiletries in Thailand. journal of consumer marketing, Vol. 15, pp. 265- 281.

Karna, J., Hansen, E., and Juslin, H. (2003). Social responsibility in environmental marketing planning. European Journal of Marketing, 37(5, 6): pp. 848-871.

Kotler, p. and Armstrong, G. (2008). Principles of marketing, New Jersey, 583.

Lee, S., Abdoullia, and Lawson-Body, A. (2010). Perceived price fairness of dynamic pricing. journal of Industrial Management \& Data 
Systems, 111, 531-550.

Mahenc, P. (2008). Signaling the environmental performance of polluting products to green consumers. International Journal of Industrial Organization, 26, 59-68.

Malhotra, N. (1988). Self concept and product choice: an integrated perspective. Journal of Economic Psychology, 9(1): pp. 1-28.

Olsan , Eric, G. (2009). Business as environmental steward: The growth of greening. Journal of business strategy, 30(5): pp. 4-13.

Polonsky. Michael Jay Rosenberger. and Philip J.(2001). Reevaluating green marketing: A strategic approach, Business Horizons ,pp 21-29.

Rahbar, E. (2008). To Buy Green and non-Green Products: What Are The Factors Influencing Customer Purchase Behavior. (MBA Thesis), University Sains Malaysia.

Rex, E. and Baumann, H. (2007). Beyond Ecolab les: what green marketiug Can learn from conven tional marketiug . journal of Cleaner Prodacfion, Vol. 15,pp 567-576.

Tondkar, H., Ramezanian, M., and Esmaeilpour, R. (2010). Impact of Green Marketing Mix on Consumer Decision Making Process. Journal of Business Management, 5(2): pp 98-79.

Xia, L. Herrmann, A. Monroe, K. B., and Huber, F. (2007). The influence of price fairness on customer satisfaction: an empirical test in the context of automobile purchases. Journal of Product \& Brand Management, 16, pp 49-58. 